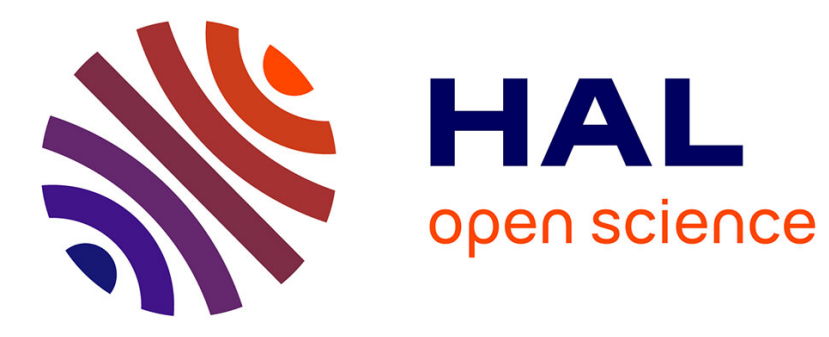

\title{
Non-HFE hemochromatosis: Pathophysiological and diagnostic aspects.
}

Edouard Bardou-Jacquet, Zeineb Ben Ali, Marie-Pascale Beaumont-Epinette, Olivier Loréal, Anne-Marie Jouanolle, Pierre Brissot

\section{To cite this version:}

Edouard Bardou-Jacquet, Zeineb Ben Ali, Marie-Pascale Beaumont-Epinette, Olivier Loréal, AnneMarie Jouanolle, et al.. Non-HFE hemochromatosis: Pathophysiological and diagnostic aspects.. Clinics and Research in Hepatology and Gastroenterology, 2013, 38 (2), pp.143-154. 10.1016/j.clinre.2013.11.003 . hal-00925741

\section{HAL Id: hal-00925741}

\section{https://hal-univ-rennes1.archives-ouvertes.fr/hal-00925741}

Submitted on 8 Jan 2014

HAL is a multi-disciplinary open access archive for the deposit and dissemination of scientific research documents, whether they are published or not. The documents may come from teaching and research institutions in France or abroad, or from public or private research centers.
L'archive ouverte pluridisciplinaire HAL, est destinée au dépôt et à la diffusion de documents scientifiques de niveau recherche, publiés ou non, émanant des établissements d'enseignement et de recherche français ou étrangers, des laboratoires publics ou privés. 


\section{Non HFE Hemochromatosis: PathophysiologICAL and diagnosTIC ASPECTS}

Edouard Bardou-Jacquet ${ }^{1,2,3}$, Zeineb Ben Ali ${ }^{1,3}$, Marie-Pascale Beaumont-Epinette ${ }^{1,4}$, Olivier Loreal ${ }^{1,2}$, AnneMarie Jouanolle ${ }^{1,4}$, Pierre Brissot ${ }^{1,2,3}$.

1) University Hospital of Rennes, French reference centre for rare iron overload diseases of genetic origin Rennes, FR

2) University of Rennes1, Inserm UMR 991, Rennes, FR 35000

3) University Hospital of Rennes, Liver disease department, Rennes, FR

4) University Hospital of Rennes, Molecular Genetics Department, Rennes, FR

\section{Running Title: Non HFE HH}

\section{Corresponding Author:}

- $\quad$ Edouard Bardou-Jacquet.

- $\quad$ Université Rennes1, Inserm UMR 991, 2 rue Henri Le Guilloux, Rennes, FR 35000

- $\quad$ Phone +33299284297 Fax : +33299284112

- Mail : edouard.bardou-jacquet@chu-rennes.fr 


\begin{abstract}
Rare genetic iron overload diseases are an evolving field due to major advances in genetics and molecular biology. Genetic iron overload has long been confined to the classical type 1 hemochromatosis related to the HFE C282Y mutation. Breakthroughs in the understanding of iron metabolism biology and molecular mechanisms led to the discovery of new genes and subsequently new types of hemochromatosis. To date four types of hemochromatosis have been identified: HFE-related or type1 hemochromatosis, the most frequent form in Caucasians, and four rare types, named type 2 ( $A$ and $B$ ) hemochromatosis (juvenile hemochromatosis due to hemojuvelin and hepcidin mutation), type 3 hemochromatosis (related to transferrin receptor 2 mutation), and type 4 ( $A$ and $B$ ) hemochromatosis (ferroportin disease). The diagnosis relies on the comprehension of the involved physiological defect , that can now be explored by biological and imaging tools, which allow non invasive assessment of iron metabolism. A multidisciplinary approach is essential to support the physicians in the diagnosis and management of those rare diseases.
\end{abstract}




\section{Introduction}

Since the description of Hemochromatosis by Trousseau in 1865, and the demonstration of its genetic nature ${ }^{1}$, many studies have shed light on its putative pathophysiological mechanism. The first major breakthrough was the discovery of the HFE gene ${ }^{2}$. This made it possible to diagnose the most common form of hereditary hemochromatosis (HFE or Type 1 hemochromatosis) due to the p.Cys282Tyr mutation (C282Y) in the HFE gene. Further discoveries unraveled iron metabolism regulation and its molecular mechanism, leading to the description of new and rarer form of hemochromatosis which are referred as non HFE hemochromatosis. Hepcidin, which is coded by the HAMP gene ${ }^{3}$, plays a central role ${ }^{4,5}$. Mainly secreted by the liver ${ }^{6,7}$, this small peptide was shown to interact with ferroportin ${ }^{8}$ (coded by the SLC40A1 gene), the only known cellular iron exporter, this interaction inducing ferroportin internalization and degradation. Thus, through its regulation of ferroportin, hepcidin can reduce iron export from macrophages and enterocytes into the bloodstream. The Transferrin Receptor $2^{9,10}$ (TFR2, coded by the TFR2 gene) and Hemojuvelin ${ }^{11-13}$ (coded by the HJV gene) are critical cofactors in hepcidin secretion regulation. Each of these genes can have mutation leading to different peculiar forms of Hemochromatosis, whose phenotypical expression can share common signs or have specific features. These discoveries, and the broader availability of genetic testing, enabled a better discrimination of HFE and non-HFE related Hemochromatosis from various secondary causes of iron overload. However, if physiology needs to be known for enlightening the expression of these conditions, it makes the diagnosis workup more complex since the phenotype can be mixed and the appropriate tests to perform difficult to choose. This emphasizes the relevant role of referral centers who can provide guidelines, genetic advice, and in-house genotyping testing to support physicians for proper evaluation of their patients with suspected rare genetic iron overload syndromes. 
PHYSIOLOGY AND PATHOLOGY

IRON METABOLISM

IRON UPTAKE AND EXPORT

Iron uptake occurs in the proximal part of the duodenum where two forms of iron are available: heme iron, mainly found in meat from the degradation of myoglobin and hemoglobin, and non heme iron found in vegetable and grains. Heme iron is carried out by endocytosis through the apical membrane of enterocytes, possibly by the Heme Carrier Protein $1^{14}$; the subsequent catabolism pathways are not yet definitely demonstrated. Non heme iron is transported into the cytoplasm of enterocytes by Divalent Metal Transporter $1{\text { (DMT1 })^{15} \text {. Ferroportin (SLCA4OA1) }}^{16-18}$ is the only known cell iron exporter, located at the basal membrane of enterocytes and at the membrane of macrophages, where it allows iron egress from the cytoplasm to the bloodstream with subsequent oxidation by hephaestin ${ }^{19}$ and binding to transferrin (Figure 1).

HEPCIDIN

Hepcidin (HAMP) is a small peptide, first identified as an antimicrobial peptide ${ }^{4-6}$. Mainly synthesized in the liver by hepatocytes, it is also produced at a lower level by adipocytes ${ }^{20}$ and macrophages ${ }^{21}$. Highly expressed in iron overload and inflammation ${ }^{4,22}$, hepcidin was later shown to be the key hormone of iron metabolism regulation ${ }^{7,23,24}$. Hepcidin interacts with ferroportin: circulating hepcidin binds to membrane ferroportin and causes subsequent ferroportin internalization and degradation ${ }^{8}$ (Figure 1). As a consequence, cellular iron egress is impaired. Hepcidin causes hypoferremia by decreasing cellular release into the plasma ${ }^{25}$, therefore regulating body iron availability through influencing iron release by both enterocytes and macrophages. 
HEPCIDIN REGULATION

The regulation of hepcidin expression has been mainly studied at a transcriptional level ${ }^{26}$. In inflammation, hepcidin induction results from the signaling of interleukin-6 through its receptor and STAT3 ${ }^{27-30}$ (signal transducer and activator of STAT3). Basal expression is regulated through a bone morphogenetic protein (BMP) /SMAD pathway ${ }^{12,31-33}$. BMP6 ${ }^{34,35}$ is thought to play a major role in association with its coreceptor hemojuvelin ${ }^{11-13}(\mathrm{HJV})$, and is also involved in the response of hepcidin expression to iron stores ${ }^{36}$. Although molecular mechanisms remain not fully elucidated, it is currently accepted that HFE, TFR1, TFR2 and HJV form a complex at the hepatocyte membrane ${ }^{37-39}$, which is thought to play a major role in the sensing of iron stores according to serum transferrin saturation, with subsequent regulation of hepcidin expression ${ }^{9,40,41}$ (Figure 1). TFR2 has been reported to activate signal transduction involving MAP kinase pathway ${ }^{42}$. A post-traductional level of hepcidin activity control, which implicates the furin dependent cleavage process, has been recently highlighted ${ }^{43,44}$. 
IRON OVERLOAD

Iron overload arising from mutations in genes involved in iron metabolism are induced by two types of mechanisms

HEPCIDIN DEFICIENCY

Hepcidin deficiency is the key mechanism explaining iron overload in type HFE, HJV, HAMP and TFR2 related hemochromatosis. The corresponding mutations lead, through disturbances of signal induction cascades, to decreased hepatic synthesis of hepcidin. In HFE hemochromatosis it was demonstrated in mice and confirmed in humans that correction of liver hepcidin secretion normalized iron metabolism ${ }^{45,46}$. Hepcidin deficiency leads to a sustained and unregulated activity of ferroportin with a double patho-physiological consequence ${ }^{5,47}$. On one hand, it leads to increased duodenal absorption of iron, and on the other hand, it enhances the release by macrophages into the blood of splenic iron originating from erythrophagocytosis. The overall result is increased plasma iron concentration associated to increased transferrin saturation. Beyond a certain level of transferrin saturation, peculiar biochemical iron species appear, named non-transferrin bound iron (NTBI) ${ }^{48,49}$. NTBI has the property to be very rapidly taken up by the liver ${ }^{50}$, pancreas and heart, and therefore produces parenchymal iron excess (namely hepatocytes for the liver). Moreover, an NTBI component, called labile plasma iron (LPI) ${ }^{51,52}$, which appears whenever plasma transferrin saturation is over $75 \%$, corresponds to a potentially damaging iron species due to its high propensity for generating reactive oxygen species. 
The iron exporter Ferroportin can be involved in two types of diseases. In type A, mutations lead to a loss of activity of the protein ${ }^{53}$, and iron overload is related to decreased iron release from the macrophages as a consequence of functional deficiency. Conversely, in type $B$, the mutated ferroportin becomes resistant to hepcidin action ${ }^{54}$, thus despite an increased serum hepcidin level, the resulting "functional hepcidin deficiency" produces, through decreased ferroportin degradation, an increased ferroportin activity as in HFE hemochromatosis.

Mutations of the ceruloplasmin gene can hamper its ferroxydase activity (which transforms ferrous iron into ferric iron) which is mandatory for iron uptake by circulating transferrin after iron has been exported by ferroportin. As a consequence, excessive ferroportin degradation may occur, leading to decreased cellular export of iron ${ }^{55}$.

As one can see, in types HFE, HJV, TFR2, HAMP, and type B ferroportin hemochromatosis, cellular iron excess is due to an hepcidin deficiency with increased entry of excessive plasma iron into cells (predominantly parenchymal cells) whereas, in types A ferroportin disease and in hereditary aceruloplasminemia, cellular iron overload is related to decreased iron egress from cells with low circulating iron. These two different mechanisms have important implications both for the phenotypic expression of the diseases and for their therapeutic approaches. 


\section{ETIOLOGY}

Actors of iron metabolism can suffer genetic alterations leading to perturbations of its physiological equilibrium. According to theinvolved genes and subsequent affected mechanisms, the phenotypes differ, thus dividing hemochromatosis in different subtypes.

HFE-RELATED (TYPE 1) HEMOCHROMATOSIS

HFE related hemochromatosis ${ }^{56}$ is the classical, and first described form, of genetic iron overload. The $H F E$ gene located on chromosome 6 codes for the membrane protein HFE, a MCH-Like protein whose definite role at the membrane remains unclear. Associated with $\beta 2$-globulin, TFR1 and potentially TFR2 and HJV, it plays a critical role in iron load sensing to regulate hepcidin secretion ${ }^{9,37-40}$. However, the definite subsequent signaling cascade, although interacting with the BMP/SMAD pathway, remains to be determined. Alterations in the protein can eventually lead to a decreased and unregulated hepcidin secretion, promoting iron absorption and iron overload ${ }^{57-61}$. The paramount role of liver in this alteration of iron metabolism has been proven by its evolution after liver transplantation in humans ${ }^{46}$.

The most frequent and classical mutation of this gene is the p.Cys282Tyr (C282Y) mutation, which can lead to iron overload when present in the homozygous state ${ }^{62}$. The mutation prevalence is high in Caucasian populations ${ }^{63,64}$ ( $10 \%$ of the subjects are heterozygous, 3 to 5 subjects per thousand are homozygous), but almost absent in the non Caucasian populations ${ }^{65}$. Other genotypes than C282Y homozygosity cannot explain overt hemochromatosis : $\mathrm{C} 282 \mathrm{Y}$ heterozygosity, H63D heterozygosity or homozygosity and compound heterozygosity $\mathrm{C} 282 \mathrm{Y} / \mathrm{H} 63 \mathrm{D}$ do not result in clinically significant iron overload in the absence of cofactors accounting for disturbed iron metabolism (alcoholism or metabolic syndrome) ${ }^{66,67}$. However some patients with compound heterozygosity C282Y/H63D may have, even without known cofactors, increased transferrin saturation and serum ferritin suggesting mild to moderate iron overload. Although they won't develop overt iron overload, and because many patients with C282Y homozygosity will also have only mild to moderate iron overload, the clinical relevance of compound heterozygosity is still debated. Moreover there is currently no data to define, biologically or clinically, what is a significant iron overload advocating for further diagnosis 
workup. Thus the role of compound heterozygosity in the diagnosis remains elusive in clinical guidelines ${ }^{68,69}$. Other rare (private) mutations of the HFE gene have been described associated to those frequent genotypes, thus explaining cases of iron overload ${ }^{70}$.

The phenotypic expression of C282Y homozygosity is quite variable, and the full-blown form of the disease (especially with cirrhosis) is rare ${ }^{71-74}$. Given that C282Y homozygosity is necessary but not sufficient for iron overload development, the role of modifying factors, impacting iron metabolism or hepcidin secretion, has been advocated. These factors can be acquired (diet ${ }^{75,76}$, alcohol ${ }^{77,78}$, hepatic dysfunction ${ }^{59}$, metabolic syndrome ${ }^{20,79,80}$ ), or genetic (gender-related ${ }^{63,64,71,81}$ or iron genes-related factors: well documented in mice ${ }^{82-}$ ${ }^{84}$, the modifying role of associated genes of iron metabolism appears more mitigated in humans ${ }^{85-89}$ ).

JUVENILE (TYPE 2) HEMOCHROMATOSIS

Described before the availability of genetic testing ${ }^{90}$ this rare disease encompasses two entities characterized by the usual young age at diagnosis. Type $2 \mathrm{~A}$ hemochromatosis is due to mutation of the hemojuvelin (HJV) gene ${ }^{91}$ on chromosome 1 and type $2 B$ is due to mutations of the hepcidin (HAMP) gene ${ }^{92}$ itself, located on chromosome 19. Both are autosomal recessive diseases. It is a particularly severe form of hemochromatosis, usually affecting young patients (<30 years old), often associated with cardiac involvement and central endocrine impact (hypogonadotropic hypogonadism). Iron overload is massive and liver fibrosis is frequent although cardiac and endocrine manifestations are at the forefront. The major and early impact of $H J V$ mutations on metabolism emphasizes its critical role in hepcidin secretion regulation. Hemojuvelin is expressed in muscle and liver, but iron metabolism is under the sole regulation of hepatocyte expressed hemojuvelin ${ }^{93}$. At the membrane of the hepatocyte, hemojuvelin act as a BMPs coreceptor modulating the BMP/SMAD pathway eventually enhancing hepcidin expression. Mutations of HAMP have obvious direct impact on hepcidin synthesis. Moreover, when associated with other form of hemochromatosis, mutations in the promoting region of $H A M P$ have been described as a worsening factor of iron overload ${ }^{94}$. 
TFR2 RELATED (TYPE 3) HEMOCHROMATOSIS

Type 3 related hemochromatosis is an autosomal recessive disease that can be considered as an "intermediate" disease between juvenile and HFE hemochromatosis. Caused by mutations of the transferrin receptor 2 gene (TFR2) located on chromosome 7, its clinical picture mimics HFE hemochromatosis although patients are usually younger and iron overload more severe ${ }^{95-101}$. Age of onset is usually described to be young adulthood ( $>30$ years old) although several report of children with type 3 hemochromatosis do suggest that peculiar genotypes or cofactors could lead to more severe and earlier diseases ${ }^{100,102}$. Cardiac and endocrine dysfunctions are less frequent than in juvenile hemochromatosis. Arthropathy is not rare. TFR2 is undoubtedly involved in hepcidin expression regulation, but its molecular mechanism remains unclear. TFR2 is complementary to HFE for hepcidin regulation according to iron load sensing ${ }^{9,40}$. Moreover, TFR2 is supposed to interact with HFE at the hepatocyte membrane and may modulate the BMP/SMAP pathway through a cross talk involving the MAP/Erk signaling pathway ${ }^{42}$.

FERROPORTIN DISEASE - TYPE 4 HEMOCHROMATOSIS

This disease is due to mutations of the ferroportin (SLC40A1) gene located on chromosome $2^{103,104}$. Unlike other types of hemochromatosis, inheritance is autosomal dominant. Although rare, it is more frequent than types 2 and 3 hemochromatosis and has been reported worldwide ${ }^{105-107}$. According to phenotypic expression it can be subdivided in two subtypes: i) Type A, the classical form, is characterized by normal or low transferrin saturation and liver biopsy shows macrophagic iron deposition ; ii) Type B variant which is more rare, is similar to types 1 and 3 hemochromatosis with elevated transferrin saturation and parenchymal iron deposition. Overall, the clinical manifestations of ferroportin disease are limited ${ }^{108}$, with only seldom cases of liver damage 
reported which were frequently associated with cofactors. Liver damage may be more frequent in type B than in type $A^{109,110}$.

As afore-mentioned, Ferroportin is the only know iron exporter at the cell membrane. In type A ferroportin disease, mutations lead to loss of iron-export function and cause iron accumulation within macrophages accounting for the predominant spleen iron overload seen by magnetic resonance imaging. Theoretically trapped in the macrophages, iron biological availability is low explaining the normal or low transferrin saturation and the potentially lower tolerance to venesections than in HFE hemochromatosis. In type B ferroportin disease, mutations lead to resistance of ferroportin to hepcidin activity, resulting in an excessive cellular iron efflux. Thus, the phenotypic picture mimicks that of type 1 Hemochromatosis with increased serum iron and transferring saturation, and parenchymal iron deposition.

OTHER RARE IRON OVERLOAD DISEASES

Hereditary a(hypo)ceruloplasminemia is due to mutations of the ceruloplasmin gene ${ }^{111}$, which either totally inhibit protein production ${ }^{112}$ or its ferroxidase activity ${ }^{113}$. Clinically, iron overload is associated with anemia and neurological symptoms. Other rare entities are presenting as anemia and iron overload syndromes: they are related to mutations of transferrin (atransferrinemia) ${ }^{114}$, DMT1 (Divalent Metal Transporter1) ${ }^{115-118}, \mathrm{X}_{\text {linked }}$ sideroblastic anemia $\left(A L A S 2^{119}, A B C 7^{120}\right)$, or glutaredoxin 5 (GRLX5) genes ${ }^{121}$. 


\section{DIAGNOSIS WORK UP}

The diagnosis work up of iron overload involves crucial steps to avoid misleading diagnosis due to confounding factors, and to optimize resource utilization. Many tools have been made available to help the physicians in this sequential strategy. Reference centers can ultimately be of primary importance to discuss difficult cases and assess the need for further specific explorations.

CAUSES OF REFERRAL, CLINICAL PRESENTATION

Clinical features associated with iron overload are diverse and can be more or less associated: asthenia, impotence due to endocrinopathy, arthropathy and osteopenia, skin darkening, hepatomegaly and moderate transaminase increase, diabetes, cardiomyopathy (cardiac failure or rhythm disturbance). However, due to improved knowledge of the disease and more widespread screening, the currently major cause of referral is elevated serum ferritin level, detected in the context of suspected iron overload, or uncovered during routine biological check-up or work up for other suspected diseases.

\section{TO ASCERTAIN IRON OVERLOAD}

The first step is to confirm that elevated serum ferritin is related to iron overload by assessing potential confounding factors, thus avoiding unnecessary explorations. This step is crucial and can be difficult as many frequent conditions can alter serum ferritin levels. Moreover, some of these causes can be associated with iron overload further increasing serum ferritin concentration. 
CONFOUNDING CAUSES OF HIGH SERUM FERRITIN

ALCOHOL CONSUMPTION

Alcohol can increase serum ferritin levels by different direct means: alcohol itself can induce ferritin synthesis ${ }^{122}$, and inhibit hepcidin synthesis which can lead to mild iron overload ${ }^{78}$. Moreover, alcohol can increase serum ferritin by indirect means: as hepatocytes are the main storage sites of ferritin, cell lysis related to alcoholic liver disease leads to release of ferritin in the bloodstream. Thus, serum ferritin should be interpreted with care in case of alcohol consumption and should be, if possible, controlled after a few months of abstinence. It should be kept in mind that marked fluctuations of serum ferritin levels are highly suggestive of intermittent phases of excessive alcohol consumption.

METABOLIC SYNDROME

The definition of the metabolic syndrome initially suffered of controversy, but is now admitted to be ${ }^{123}$ :

- Increased waist circumference (94cm in man and 80 in women, with population specific definitions)

- Increased triglycerides (or specific treatment): $>1.7 \mathrm{mmol} / \mathrm{L}$

- Reduced HDL cholesterol (or specific treatment): $<1 \mathrm{mmol} / \mathrm{L}$ in men and $1.3 \mathrm{mmol} / \mathrm{L}$ in women

- Increased blood pressure (or specific treatment): Systolic $\geq 130$ and/or diastolic $\geq 85 \mathrm{~mm} \mathrm{Hg}$

- Increased fasting glucose (or specific treatment) : $>5.5 \mathrm{mmol} / \mathrm{L}$ 
Metabolic syndrome is one of the most frequent causes of hyperferritinemia. Metabolic syndrome can be associated with hyperferritinemia (often comprised between 500 and $1200 \mu \mathrm{g} / \mathrm{L}$ ) without or with mild iron overload $^{124}$ (insulin resistance associated iron overload or dysmetabolic hepatosiderosis) and is usually associated with increased serum hepcidin levels ${ }^{125}$. However, iron burden remains of lower intensity as compared to the pronounced serum ferritin increase. Serum transferrin saturation is usually normal although it can sometimes be slightly increased. It leads frequently to an erroneous diagnosis of hemochromatosis.

INFLAMMATION

In the acute or chronic phase of inflammation, ferritin can be mobilized without iron excess, thus leading to high serum ferritin which can range from mild to very high levels. One should think of inflammation especially when serum iron is low. Therefore plasma C reactive protein (CRP) should always be part of the work up for hyperferritinemia.

LIVER DAMAGE

Acute or chronic liver injury resulting in hepatocyte damage can lead to increased serum ferritin regardless of the underlying cause. Actually, ferritin is mainly stored in hepatocytes and serum ferritin is a only minor part of total body ferritin stores and is used as a surrogate marker. Thus, similarly to aspartate amino transferase and alanine aminotransferase, intracellular ferritin can be released into the bloodstream secondary to hepatocyte injury. The determination of serum transaminase activities is therefore another important parameter to control for proper interpretation of hyperferritinemia. 
RARE CAUSES OF ELEVATED SERUM FERRITIN

Some peculiar conditions can be associated with high serum ferritin without iron overload

- Hereditary Hyperferritinemia-Cataract Syndrome

Mutation in the Iron Responsive Element in the non-coding region of the messenger RNA of the L-Ferritin gene (FTL, coding for the light subunit of ferritin) causes hyperferritinemia (which can be very elevated, often above $1000 \mu \mathrm{g} / \mathrm{L}$ ) associated, in the classical form, with an history of familial cataracts, often expressed in young subjects and leading to early surgical treatment ${ }^{126-128}$. Transmission is autosomal dominant. This condition is not associated with iron overload and thus there is no indication for venesection therapy. Although long term data are scarce, there is currently no data that advocate for a negative consequence of chronically elevated serum ferritin in this context. Beside this classical form, mutations in the coding region of the FTL gene have been recently described ${ }^{127}$. Those mutations, referred to as Hereditary L Ferritin syndrome in figure 2, lead to elevated serum ferritin without iron overload or cataract.

- Gaucher's disease

Gaucher's disease can be associated with high serum ferritin and normal transferrin saturation. It is an inherited metabolism anomaly (glucocerebrosidase deficiency) resulting in excessive storage of glucocerebroside in the liver, spleen, bone, and bone marrow. The clinical signs are anemia, thrombocytopenia, hepatosplenomegaly, and bone pain. Elevated serum ferritin is not at the forefront of the clinical picture and should not postpone referral to a referent center. 
- Macrophage activation syndrome

Hyperferritinemia, which is a diagnosis criteria, is massively elevated ( $>5000 \mu \mathrm{g} / \mathrm{L}$ ) in the context of infectious (EBV), inflammatory (Still's syndrome) or hematological diseases. It is associated with general symptoms (fever, splenomegaly, cytopenia, high serum triglyceride levels) that need urgent referral for treatment.

\section{TO QUANTIFY IRON OVERLOAD}

Once iron overload is suspected by elevated serum ferritin, and the potential confounding factors have been assessed, the next step is to assess body iron stores to quantify iron overload. Serum transferrin saturation should first be performed. If elevated HFE related hemochromatosis is the most likely diagnosis in the Caucasian population and should thus be confirmed by HFE C282Y testing before further exploration. Lack of C282Y homozygosity requires definite evaluation of iron overload.

Using the paramagnetic property of iron, Magnetic resonance imaging (MRI) is a fast and efficient non invasive technique to assess liver iron concentration ${ }^{129,130}$. It requires an 1,5 Tesla MRI device (which is the most frequent) and the algorithm for iron evaluation proposed by the Rennes University is freely accessible on the website www.radio.univ-rennes1.fr.

A region of interest is drawn to compare the T2 signal between liver and paravertebral muscle, hyposignal (meaning dark liver as compared to paravertebral muscles), representing higher tissue iron concentrations. The very good correlation between hyposignal and hepatic iron overload allows to determine hepatic iron concentration with a satisfactory reliability. Moreover, it is highly relevant to evaluate hepatic versus an approximation of splenic iron load since a dominant splenic iron excess means preferential macrophagic iron deposition, therefore orientating the diagnosis towards transfusional iron excess or ferroportin disease ${ }^{131}$.

Alternative methods, using T2 relaxometry have been developed and are found to be more accurate to quantify liver iron content at all levels of iron overload ${ }^{130,132}$. However due to hardware requirement and lack of standardization they are not yet widely available. 
If MRI is not available or contra-indicated, liver biopsy, using Perls staining, remains a reference method for diagnosing iron excess ${ }^{133}$. Biochemical determination of iron concentration remains the gold standard. Moreover, liver biopsy gives definite information regarding parenchymal or mesenchymal localization of iron overload which can be helpful in the diagnosis workup (review in Deugnier et al. ${ }^{134}$ ). However, due to its invasive nature, morbidity, cost and the increasing place of MRI, liver biopsy is rarely needed for diagnosing the type of iron overload. Indications today are mainly to evaluate iron overload consequences in terms of hepatic fibrosis and to search for possible co-factors such as steatohepatitis (alcoholic or not (NASH)). Regarding fibrosis evaluation, there is growing evidence that non invasive procedures such as serum markers and/or transient elastography, can give relevant information ${ }^{135,136}$.

\section{PRIMARY OR SECONDARY IRON OVERLOAD}

Once iron overload has been identified and quantified, its primary or secondary nature must be determined.

Oral supplementation, although rarely, can lead to iron overload ${ }^{137}$. It is thus necessary, through careful questioning, to ensure that the patient has not undergone prolonged iron supplementation. It is of major importance to assess this point in patient seeking sportive performance for professional ${ }^{138}$ or non-professional reasons, as it has been considered that iron supplementation could increase hemoglobin status.

The main cause of secondary iron overload is represented by hematological conditions. Chronic or rare anemias such as thalassemia major, sickle cell disease, myelodysplatic syndromes, and congenital anemias, can be associated with iron overload.

Two, more or less associated, mechanisms can be involved:

- Increased iron load through repeated transfusions represents, a major cause of iron overload (each transfused unit provides $200-250 \mathrm{mg}$ of iron so that significant iron excess develops after $10-20$ units). This 
mechanism leads to an increased recycling of red blood cells process with enhanced iron deposition within macrophages, mainly in the spleen but also in hepatic Kupffer cells.

- Hepcidin deficiency. Ineffective erythropoiesis leads, through a yet not clearly defined pathway, to inhibition of hepcidin expression. The proposed role of Growth Differentiation Factor $15{ }^{139}$ is now questioned since a more direct link between erythropoiesis and hepcidin secretion has been recently reported. Indeed, a major breakthrough is represented by the discovery of the hormone named erythroferrone which corresponds very likely to the long-sought "erythropoietic factor" (Kautz et al, 2013, Biolron, London). This could explain why iron overload can develop in chronic anemia, like thalassaemia, even in the absence of transfusions ${ }^{140}$, and why hepcidin expression is relatively low in those diseases despite transfusional iron excess (which should lead to increased hepcidin expression).

Past history of chemotherapy treatment should also be sought. Growth factor or sometimes multiple transfusions used in this context can also lead to iron overload. The long term outcome of "transitional" secondary iron overload is not known, but due to the absence of natural and effective iron elimination route, it is likely that iron overload can persist for years.

\section{TO IDENTIFY THE GENETIC ORIGIN OF IRON OVERLOAD}

Identification of the genetic cause of primary iron overload is driven by the combination of patient's clinical and biological data that suggest the possible underlying physiological mechanism.

A precise determination of the suspected disease is highly recommended as most of the genetic studies are not performed in routine and are both expensive and time consuming. Thus, a multidisciplinary approach is often required in complex cases and the help of referral centers should be sought.

As an example, in France, a national reference center, working in a nextwork with several regional competence centers, has been established (http://www.centre-reference-fer-rennes.org/) and proposes, on a weekly basis, multidisciplinary meetings where difficult cases are discussed in order to support physicians in their diagnosis work-up. 
PATIENT AND FAMILY DATA

Patient's clinical and biological data have to be gathered through the initial phases of work-up. It should be emphasized that, due to important between and within-day variations of iron biological parameters (especially serum iron and transferrin saturation ${ }^{141,142}$ ), repeated measurements should be performed especially to avoid false positive results.

Family history is a major point to assess. Careful search for putative diagnosis of iron overload in relatives can suggest the presence of a dominant or recessive disease and strengthen the need for genetic exploration.

DECISION TREE

The decision tree is summarized in Figure 2.

Serum transferrin saturation is the initial key point.

- Increased transferrin saturation

The most likely diagnosis in Caucasians is HFE related (or type 1) hemochromatosis as confirmed by C282Y homozygosity. If there is a family history of dominant transmission the type B ferroportin disease (hemochromatosis 4B) should be sought.

If the C282Y HFE mutation is absent, the next relevant information is the age of presentation: in young patients (<30 years old) either type $A$ (hemojuvelin mutations) or type $B$ (hepcidin mutation) juvenile hemochromatosis (type 2 hemochromatosis) should be looked for. In older patients, transferrin receptor 2 mutation (or type 3 hemochromatosis), type B ferroportin disease (hemochromatosis 4B) or private mutations of the HFE gene (which require complete sequencing of the gene instead of routine HFE C282Y test) can be evoked. However 
patient with very early presentation of type 3 hemochromatosis have been reported, and conversely patient with type 2 hemochromatosis and late presentation have also been reported. Thus if age is a clue for deciding which genetic test should be performed at first, if negative an unusual age of presentation must be considered.

- Normal or low transferrin saturation

In this case, the most likely diagnosis is the classical form of ferroportin disease (type A) which can be confirmed be sequencing. However, given its simplicity, plasma ceruloplasmin levels should also be determined despite the rarity of hereditary aceruloplasminemia. The latter diagnosis will of course be more likely in cases of anemia and/or neurological symptoms. Ceruloplasmin levels are typically not detectable but, in some cases, ceruloplasminemia is only significantly decreased.

MANAGEMENT OF NON HFE HEMOCHROMATOSIS

FAMILY SCREENING

Family screening is very important in the management of patients with genetic iron overload. It can provide precious clues in the diagnosis work-up of the patient but also help to determine if a genetic anomaly is a pathogenic mutation or a simple polymorphism by studying the genotype / phenotype correlations within the family. Mostly, family screening, following the diagnosis of a specific mutation in a given patient, allows earlier diagnosis thus preventing the development of iron-related organ damage related .

PHLEBOTOMY 
The mainstay of treatment in genetic iron overload is removal of iron burden. Phlebotomies (venesections) remain the most efficient and convenient way to remove iron by forcing the bone marrow to use stored iron for intense erythropoiesis.

Treatment is performed in non-HFE hemochromatosis in a similar way to that of the type 1 form. The initial induction phase will remove the excessive iron and the maintenance phase will prevent its recurrence ${ }^{143}$.

During induction phase, phlebotomy is performed on a weekly basis using a weight based volume of $7 \mathrm{ml} / \mathrm{Kg}$ up to $550 \mathrm{ml}$. Hemoglobin should be monitored on a monthly basis. In case of anemia treatment should be postponed until resolution ; if necessary volume and / or frequency of phlebotomy should be reduced. Serum ferritin is monitored to assess treatment efficiency. Monitoring frequency relies upon serum ferritin value: monthly as long as ferritin remains above the normal range, then fortnightly until the goal of $50 \mu \mathrm{g} / \mathrm{L}$ is reached.

Once iron depletion has been achieved, the aim of maintenance treatment is to prevent recurrence of iron overload. Venesection is thus performed every 2-4 months to maintain a serum ferritin value close to $50 \mu \mathrm{g} / \mathrm{L}$.

Special attention should be given to iron overload related to iron transport anomalies, like ferroportin disease, as anemia could occur more frequently. Therefore, hemoglobin levels should be closely monitored and phlebotomies should be performed initially less frequently to test for hematological tolerance.

OTHER THERAPEUTIC ASPECTS

DIET

Although very commonly questioned by patients, and probably partially involved in the variable expression of the disease, no studies showed beneficial effect of dietary modification or alimentary iron avoidance in patient undergoing phlebotomy treatment. Thus, it is advised to maintain a healthy diet without stringent restrictions regarding iron. However, iron supplemented food should be avoided and it is usually recommended to limit vitamin C intake due to its possible toxic effect. 
Special emphasis should be given to alcohol consumption. It has been clearly shown that, like in many liver diseases, excessive alcohol consumption increases liver damage ${ }^{77}$. Moreover, a direct inhibition effect of alcohol on hepcidin secretion favors iron overload.

ORAL CHELATION

Deferasirox $\left(\right.$ Exjade $\left.^{\circledR}\right)$ is an oral iron chelator, which, taken once daily, is used in post-transfusional iron overload. An international study in HFE hemochromatosis showed satisfactory results regarding safety and efficiency ${ }^{144}$. Although off label, this treatment could be helpful in case of contraindication (anemia) or poor tolerance to phlebotomy. Moreover, it could be useful, in addition to venesections, in patients with massive iron overload and organ damage requiring very rapid removal of iron burden. 
1. Simon M, Bourel M, Genetet B, Fauchet R. Idiopathic hemochromatosis. Demonstration of recessive transmission and early detection by family HLA typing. N Engl J Med 1977;297:1017-21.

2. Feder JN, Gnirke A, Thomas W, et al. A novel MHC class I-like gene is mutated in patients with hereditary haemochromatosis. Nat Genet 1996;13:399-408.

3. Krause A, Neitz S, Magert HJ, et al. LEAP-1, a novel highly disulfide-bonded human peptide, exhibits antimicrobial activity. FEBS Lett 2000;480:147-50.

4. Pigeon C, Ilyin G, Courselaud B, et al. A new mouse liver-specific gene, encoding a protein homologous to human antimicrobial peptide hepcidin, is overexpressed during iron overload. J Biol Chem 2001;276:7811-9.

5. Nicolas G, Bennoun M, Devaux I, et al. Lack of hepcidin gene expression and severe tissue iron overload in upstream stimulatory factor 2 (USF2) knockout mice. Proc Natl Acad Sci U S A 2001;98:8780-5.

6. Park $\mathrm{CH}$, Valore EV, Waring AJ, Ganz T. Hepcidin, a urinary antimicrobial peptide synthesized in the liver. J Biol Chem 2001;276:7806-10.

7. Ganz T. Hepcidin and iron regulation, 10 years later. Blood 2011;117:4425-33.

8. Nemeth E, Tuttle MS, Powelson J, et al. Hepcidin regulates cellular iron efflux by binding to ferroportin and inducing its internalization. Science 2004;306:2090-3.

9. Gao J, Chen J, Kramer M, Tsukamoto H, Zhang AS, Enns CA. Interaction of the hereditary hemochromatosis protein HFE with transferrin receptor 2 is required for transferrin-induced hepcidin expression. Cell Metab 2009;9:217-27.

10. Corradini E, Rozier M, Meynard D, et al. Iron regulation of hepcidin despite attenuated Smad1,5,8 signaling in mice without transferrin receptor 2 or Hfe. Gastroenterology 2011;141:1907-14.

11. Andriopoulos B, Jr., Corradini E, Xia Y, et al. BMP6 is a key endogenous regulator of hepcidin expression and iron metabolism. Nat Genet 2009;41:482-7.

12. Babitt JL, Huang FW, Wrighting DM, et al. Bone morphogenetic protein signaling by hemojuvelin regulates hepcidin expression. Nat Genet 2006;38:531-9.

13. Babitt JL, Huang FW, Xia Y, Sidis Y, Andrews NC, Lin HY. Modulation of bone morphogenetic protein signaling in vivo regulates systemic iron balance. J Clin Invest 2007;117:1933-9.

14. Shayeghi M, Latunde-Dada GO, Oakhill JS, et al. Identification of an intestinal heme transporter. Cell 2005;122:789-801.

15. Gunshin H, Fujiwara Y, Custodio AO, Direnzo C, Robine S, Andrews NC. Slc11a2 is required for intestinal iron absorption and erythropoiesis but dispensable in placenta and liver. J Clin Invest 2005;115:1258-66.

16. Abboud S, Haile DJ. A novel mammalian iron-regulated protein involved in intracellular iron metabolism. J Biol Chem 2000;275:19906-12.

17. McKie AT, Marciani P, Rolfs A, et al. A novel duodenal iron-regulated transporter, IREG1, implicated in the basolateral transfer of iron to the circulation. Mol Cell 2000;5:299-309.

18. Donovan A, Brownlie A, Zhou Y, et al. Positional cloning of zebrafish ferroportin1 identifies a conserved vertebrate iron exporter. Nature 2000;403:776-81.

19. Vulpe CD, Kuo YM, Murphy TL, et al. Hephaestin, a ceruloplasmin homologue implicated in intestinal iron transport, is defective in the sla mouse. Nat Genet 1999;21:195-9.

20. Bekri S, Gual P, Anty R, et al. Increased adipose tissue expression of hepcidin in severe obesity is independent from diabetes and NASH. Gastroenterology 2006;131:788-96.

21. Peyssonnaux C, Zinkernagel AS, Datta V, Lauth X, Johnson RS, Nizet V. TLR4-dependent hepcidin expression by myeloid cells in response to bacterial pathogens. Blood 2006;107:3727-32.

22. Nemeth E, Valore EV, Territo M, Schiller G, Lichtenstein A, Ganz T. Hepcidin, a putative mediator of anemia of inflammation, is a type II acute-phase protein. Blood 2003;101:2461-3.

23. Nicolas G, Viatte L, Bennoun M, Beaumont C, Kahn A, Vaulont S. Hepcidin, a new iron regulatory peptide. Blood Cells Mol Dis 2002;29:327-35.

24. Ganz T. Molecular control of iron transport. J Am Soc Nephrol 2007;18:394-400.

25. Rivera S, Nemeth E, Gabayan V, Lopez MA, Farshidi D, Ganz T. Synthetic hepcidin causes rapid dosedependent hypoferremia and is concentrated in ferroportin-containing organs. Blood 2005;106:2196-9. 
26. Courselaud B, Pigeon C, Inoue $\mathrm{Y}$, et al. C/EBPalpha regulates hepatic transcription of hepcidin, an antimicrobial peptide and regulator of iron metabolism. Cross-talk between C/EBP pathway and iron metabolism. J Biol Chem 2002;277:41163-70.

27. Fatih N, Camberlein E, Island ML, et al. Natural and synthetic STAT3 inhibitors reduce hepcidin expression in differentiated mouse hepatocytes expressing the active phosphorylated STAT3 form. J Mol Med (Berl) 2010;88:477-86.

28. Pietrangelo A, Dierssen U, Valli L, et al. STAT3 is required for IL-6-gp130-dependent activation of hepcidin in vivo. Gastroenterology 2007;132:294-300.

29. Verga Falzacappa MV, Vujic Spasic M, Kessler R, Stolte J, Hentze MW, Muckenthaler MU. STAT3 mediates hepatic hepcidin expression and its inflammatory stimulation. Blood 2007;109:353-8.

30. Wrighting DM, Andrews NC. Interleukin-6 induces hepcidin expression through STAT3. Blood 2006;108:3204-9.

31. Truksa J, Peng $\mathrm{H}$, Lee $\mathrm{P}$, Beutler E. Bone morphogenetic proteins 2, 4, and 9 stimulate murine hepcidin 1 expression independently of $\mathrm{Hfe}$, transferrin receptor 2 (Tfr2), and IL-6. Proc Natl Acad Sci U S A 2006;103:10289-93.

32. Wang $\mathrm{RH}, \mathrm{Li} \mathrm{C}, \mathrm{Xu} \mathrm{X}$, et al. A role of SMAD4 in iron metabolism through the positive regulation of hepcidin expression. Cell Metab 2005;2:399-409.

33. Steinbicker AU, Bartnikas TB, Lohmeyer LK, et al. Perturbation of hepcidin expression by BMP type I receptor deletion induces iron overload in mice. Blood 2011;118:4224-30.

34. Kautz L, Meynard D, Monnier A, et al. Iron regulates phosphorylation of Smad1/5/8 and gene expression of Bmp6, Smad7, Id1, and Atoh8 in the mouse liver. Blood 2008;112:1503-9.

35. Meynard D, Kautz L, Darnaud V, Canonne-Hergaux F, Coppin H, Roth MP. Lack of the bone morphogenetic protein BMP6 induces massive iron overload. Nat Genet 2009;41:478-81.

36. Ramos E, Kautz L, Rodriguez $R$, et al. Evidence for distinct pathways of hepcidin regulation by acute and chronic iron loading in mice. Hepatology 2011;53:1333-41.

37. D'Alessio F, Hentze MW, Muckenthaler MU. The hemochromatosis proteins HFE, TfR2, and HJV form a membrane-associated protein complex for hepcidin regulation. J Hepatol 2012;57:1052-60.

38. Wallace DF, Summerville L, Crampton EM, Frazer DM, Anderson GJ, Subramaniam VN. Combined deletion of $\mathrm{Hfe}$ and transferrin receptor 2 in mice leads to marked dysregulation of hepcidin and iron overload. Hepatology 2009;50:1992-2000.

39. Schmidt PJ, Fleming MD. Transgenic HFE-dependent induction of hepcidin in mice does not require transferrin receptor-2. Am J Hematol 2012;87:588-95.

40. Goswami T, Andrews NC. Hereditary hemochromatosis protein, HFE, interaction with transferrin receptor 2 suggests a molecular mechanism for mammalian iron sensing. J Biol Chem 2006;281:28494-8.

41. Johnson $\mathrm{MB}$, Enns CA. Diferric transferrin regulates transferrin receptor 2 protein stability. Blood 2004;104:4287-93.

42. Calzolari A, Raggi C, Deaglio S, et al. TfR2 localizes in lipid raft domains and is released in exosomes to activate signal transduction along the MAPK pathway. J Cell Sci 2006;119:4486-98.

43. Valore EV, Ganz T. Posttranslational processing of hepcidin in human hepatocytes is mediated by the prohormone convertase furin. Blood Cells Mol Dis 2008;40:132-8.

44. Silvestri L, Pagani A, Camaschella C. Furin-mediated release of soluble hemojuvelin: a new link between hypoxia and iron homeostasis. Blood 2008;111:924-31.

45. Garuti C, Tian Y, Montosi G, et al. Hepcidin expression does not rescue the iron-poor phenotype of Kupffer cells in Hfe-null mice after liver transplantation. Gastroenterology 2010;139:315-22 e1.

46. Bardou-Jacquet E, Philip J, Lorho R, et al. Liver transplantation normalizes serum hepcidin level and cures iron metabolism alterations in HFE hemochromatosis. Hepatology 2013.

47. Papanikolaou G, Tzilianos M, Christakis Jl, et al. Hepcidin in iron overload disorders. Blood 2005;105:4103-5.

48. Hershko C, Graham G, Bates GW, Rachmilewitz EA. Non-specific serum iron in thalassaemia: an abnormal serum iron fraction of potential toxicity. Br J Haematol 1978;40:255-63.

49. Hider RC. Nature of nontransferrin-bound iron. Eur J Clin Invest 2002;32 Suppl 1:50-4.

50. Brissot P, Wright TL, Ma WL, Weisiger RA. Efficient clearance of non-transferrin-bound iron by rat liver. Implications for hepatic iron loading in iron overload states. J Clin Invest 1985;76:1463-70.

51. Esposito BP, Breuer W, Sirankapracha P, Pootrakul P, Hershko C, Cabantchik ZI. Labile plasma iron in iron overload: redox activity and susceptibility to chelation. Blood 2003;102:2670-7.

52. Le Lan C, Loreal O, Cohen T, et al. Redox active plasma iron in C282Y/C282Y hemochromatosis. Blood 2005;105:4527-31. 
53. De Domenico I, Ward DM, Musci G, Kaplan J. Iron overload due to mutations in ferroportin. Haematologica 2006;91:92-5.

54. Drakesmith H, Schimanski LM, Ormerod E, et al. Resistance to hepcidin is conferred by hemochromatosis-associated mutations of ferroportin. Blood 2005;106:1092-7.

55. De Domenico I, Ward DM, di Patti MC, et al. Ferroxidase activity is required for the stability of cell surface ferroportin in cells expressing GPI-ceruloplasmin. Embo J 2007;26:2823-31.

56. Pietrangelo A. Hemochromatosis: an endocrine liver disease. Hepatology 2007;46:1291-301.

57. Piperno A, Girelli D, Nemeth E, et al. Blunted hepcidin response to oral iron challenge in HFE-related hemochromatosis. Blood 2007;110:4096-100.

58. Loreal $\mathrm{O}$, Haziza-Pigeon C, Troadec MB, et al. Hepcidin in iron metabolism. Curr Protein Pept Sci 2005;6:279-91.

59. Detivaud L, Nemeth E, Boudjema K, et al. Hepcidin levels in humans are correlated with hepatic iron stores, hemoglobin levels, and hepatic function. Blood 2005;106:746-8.

60. Babitt JL, Lin HY. The molecular pathogenesis of hereditary hemochromatosis. Semin Liver Dis 2011;31:280-92.

61. Murphy AT, Witcher DR, Luan P, Wroblewski VJ. Quantitation of hepcidin from human and mouse serum using liquid chromatography tandem mass spectrometry. Blood 2007;110:1048-54.

62. Jouanolle AM, Fergelot P, Gandon G, Yaouanq J, Le Gall JY, David V. A candidate gene for hemochromatosis: frequency of the C282Y and H63D mutations. Hum Genet 1997;100:544-7.

63. Adams PC, Reboussin DM, Barton JC, et al. Hemochromatosis and iron-overload screening in a racially diverse population. N Engl J Med 2005;352:1769-78.

64. Deugnier $\mathrm{Y}$, Jouanolle AM, Chaperon J, et al. Gender-specific phenotypic expression and screening strategies in C282Y-linked haemochromatosis: a study of 9396 French people. Br J Haematol 2002;118:1170-8.

65. Merryweather-Clarke AT, Pointon JJ, Shearman JD, Robson KJ. Global prevalence of putative haemochromatosis mutations. J Med Genet 1997;34:275-8.

66. Gochee PA, Powell LW, Cullen DJ, Du Sart D, Rossi E, Olynyk JK. A population-based study of the biochemical and clinical expression of the H63D hemochromatosis mutation. Gastroenterology 2002;122:64651.

67. Walsh A, Dixon JL, Ramm GA, et al. The clinical relevance of compound heterozygosity for the C282Y and H63D substitutions in hemochromatosis. Clin Gastroenterol Hepatol 2006;4:1403-10.

68. EASL clinical practice guidelines for HFE hemochromatosis. J Hepatol 2010;53:3-22.

69. Bacon BR, Adams PC, Kowdley KV, Powell LW, Tavill AS. Diagnosis and management of hemochromatosis: 2011 practice guideline by the American Association for the Study of Liver Diseases. Hepatology 2011;54:328-43.

70. Aguilar-Martinez P, Grandchamp B, Cunat S, et al. Iron overload in HFE C282Y heterozygotes at first genetic testing: a strategy for identifying rare HFE variants. Haematologica 2011;96:507-14.

71. Beutler E, Felitti VJ, Koziol JA, Ho NJ, Gelbart T. Penetrance of 845G--> A (C282Y) HFE hereditary haemochromatosis mutation in the USA. Lancet 2002;359:211-8.

72. Olynyk JK, Cullen DJ, Aquilia S, Rossi E, Summerville L, Powell LW. A population-based study of the clinical expression of the hemochromatosis gene. N Engl J Med 1999;341:718-24.

73. Waalen J, Nordestgaard BG, Beutler E. The penetrance of hereditary hemochromatosis. Best Pract Res Clin Haematol 2005;18:203-20.

74. Allen KJ, Gurrin LC, Constantine CC, et al. Iron-overload-related disease in HFE hereditary hemochromatosis. N Engl J Med 2008;358:221-30.

75. van der AD, Peeters PH, Grobbee DE, Roest M, Voorbij HA, van der Schouw YT. HFE genotypes and dietary heme iron: no evidence of strong gene-nutrient interaction on serum ferritin concentrations in middleaged women. Nutr Metab Cardiovasc Dis 2006;16:60-8.

76. Kaltwasser JP, Werner E, Schalk K, Hansen C, Gottschalk R, Seidl C. Clinical trial on the effect of regular tea drinking on iron accumulation in genetic haemochromatosis. Gut 1998;43:699-704.

77. Loreal O, Deugnier Y, Moirand R, et al. Liver fibrosis in genetic hemochromatosis. Respective roles of iron and non-iron-related factors in 127 homozygous patients. J Hepatol 1992;16:122-7.

78. Bridle K, Cheung TK, Murphy T, et al. Hepcidin is down-regulated in alcoholic liver injury: implications for the pathogenesis of alcoholic liver disease. Alcohol Clin Exp Res 2006;30:106-12.

79. Desgrippes R, Laine F, Morcet J, et al. Decreased iron burden in overweight C282Y homozygous women: Putative role of increased hepcidin production. Hepatology 2013;57:1784-92.

80. Laine F, Jouannolle AM, Morcet J, et al. Phenotypic expression in detected C282Y homozygous women depends on body mass index. J Hepatol 2005;43:1055-9. 
81. Moirand R, Adams PC, Bicheler V, Brissot P, Deugnier Y. Clinical features of genetic hemochromatosis in women compared with men. Ann Intern Med 1997;127:105-10.

82. Levy JE, Montross LK, Andrews NC. Genes that modify the hemochromatosis phenotype in mice. J Clin Invest 2000;105:1209-16.

83. Bensaid M, Fruchon S, Mazeres C, Bahram S, Roth MP, Coppin H. Multigenic control of hepatic iron loading in a murine model of hemochromatosis. Gastroenterology 2004;126:1400-8.

84. Tolosano E, Fagoonee S, Garuti C, et al. Haptoglobin modifies the hemochromatosis phenotype in mice. Blood 2005;105:3353-5.

85. Jacolot S, Le Gac G, Scotet V, Quere I, Mura C, Ferec C. HAMP as a modifier gene that increases the phenotypic expression of the HFE pC282Y homozygous genotype. Blood 2004;103:2835-40.

86. Merryweather-Clarke AT, Cadet E, Bomford A, et al. Digenic inheritance of mutations in HAMP and HFE results in different types of haemochromatosis. Hum Mol Genet 2003;12:2241-7.

87. Le Gac G, Scotet V, Ka C, et al. The recently identified type 2A juvenile haemochromatosis gene (HJV), a second candidate modifier of the C282Y homozygous phenotype. Hum Mol Genet 2004;13:1913-8.

88. Milet J, Dehais V, Bourgain C, et al. Common variants in the BMP2, BMP4, and HJV genes of the hepcidin regulation pathway modulate HFE hemochromatosis penetrance. Am J Hum Genet 2007;81:799-807.

89. Lee P, Gelbart T, West C, Halloran C, Beutler E. Seeking candidate mutations that affect iron homeostasis. Blood Cells Mol Dis 2002;29:471-87.

90. Lamon JM, Marynick SP, Roseblatt R, Donnelly S. Idiopathic hemochromatosis in a young female. A case study and review of the syndrome in young people. Gastroenterology 1979;76:178-83.

91. Papanikolaou G, Samuels ME, Ludwig EH, et al. Mutations in HFE2 cause iron overload in chromosome 1q-linked juvenile hemochromatosis. Nat Genet 2004;36:77-82.

92. Roetto A, Papanikolaou G, Politou M, et al. Mutant antimicrobial peptide hepcidin is associated with severe juvenile hemochromatosis. Nat Genet 2003;33:21-2.

93. Gkouvatsos K, Wagner J, Papanikolaou G, Sebastiani G, Pantopoulos K. Conditional disruption of mouse HFE2 gene: maintenance of systemic iron homeostasis requires hepatic but not skeletal muscle hemojuvelin. Hepatology 2011;54:1800-7.

94. Island ML, Jouanolle AM, Mosser A, et al. A new mutation in the hepcidin promoter impairs its BMP response and contributes to a severe phenotype in HFE related hemochromatosis. Haematologica 2009;94:720-4.

95. Hsiao PJ, Tsai KB, Shin SJ, et al. A novel mutation of transferrin receptor 2 in a Taiwanese woman with type 3 hemochromatosis. J Hepatol 2007;47:303-6.

96. Le Gac G, Mons F, Jacolot S, Scotet V, Ferec C, Frebourg T. Early onset hereditary hemochromatosis resulting from a novel TFR2 gene nonsense mutation (R105X) in two siblings of north French descent. $\mathrm{Br} J$ Haematol 2004;125:674-8.

97. Majore S, Milano F, Binni F, et al. Homozygous p.M172K mutation of the TFR2 gene in an Italian family with type 3 hereditary hemochromatosis and early onset iron overload. Haematologica 2006;91:ECR33.

98. Piperno A, Roetto A, Mariani R, et al. Homozygosity for transferrin receptor-2 Y250X mutation induces early iron overload. Haematologica 2004;89:359-60.

99. Roetto A, Totaro A, Piperno A, et al. New mutations inactivating transferrin receptor 2 in hemochromatosis type 3. Blood 2001;97:2555-60.

100. Bardou-Jacquet $\mathrm{E}$, Cunat $\mathrm{S}$, Beaumont-Epinette MP, et al. Variable age of onset and clinical severity in transferrin receptor 2 related haemochromatosis: novel observations. Br J Haematol 2013;162:278-81.

101. Girelli D, Bozzini C, Roetto A, et al. Clinical and pathologic findings in hemochromatosis type 3 due to a novel mutation in transferrin receptor 2 gene. Gastroenterology 2002;122:1295-302.

102. Gerolami V, Le Gac G, Mercier L, Nezri M, Berge-Lefranc JL, Ferec C. Early-onset haemochromatosis caused by a novel combination of TFR2 mutations(p.R396X/c.1538-2 A>G) in a woman of Italian descent. Haematologica 2008;93:e45-6.

103. Montosi G, Donovan A, Totaro A, et al. Autosomal-dominant hemochromatosis is associated with a mutation in the ferroportin (SLC11A3) gene. J Clin Invest 2001;108:619-23.

104. Njajou OT, Vaessen N, Joosse M, et al. A mutation in SLC11A3 is associated with autosomal dominant hemochromatosis. Nat Genet 2001;28:213-4.

105. Barton JC, Acton RT, Lee PL, West C. SLC40A1 Q248H allele frequencies and Q248H-associated risk of non-HFE iron overload in persons of sub-Saharan African descent. Blood Cells Mol Dis 2007;39:206-11.

106. Beutler E, Barton JC, Felitti VJ, et al. Ferroportin 1 (SCL40A1) variant associated with iron overload in African-Americans. Blood Cells Mol Dis 2003;31:305-9. 
107. Subramaniam VN, Wallace DF, Dixon JL, Fletcher LM, Crawford DH. Ferroportin disease due to the A77D mutation in Australia. Gut 2005;54:1048-9.

108. Le Lan C, Mosser A, Ropert M, et al. Sex and acquired cofactors determine phenotypes of ferroportin disease. Gastroenterology 2011;140:1199-207 e1-2.

109. Wallace DF, Clark RM, Harley HA, Subramaniam VN. Autosomal dominant iron overload due to a novel mutation of ferroportin1 associated with parenchymal iron loading and cirrhosis. J Hepatol 2004;40:710-3.

110. Sham RL, Phatak PD, West C, Lee P, Andrews C, Beutler E. Autosomal dominant hereditary hemochromatosis associated with a novel ferroportin mutation and unique clinical features. Blood Cells Mol Dis 2005;34:157-61.

111. Miyajima H, Takahashi Y, Kono S. Aceruloplasminemia, an inherited disorder of iron metabolism. Biometals 2003;16:205-13.

112. Yoshida K, Furihata K, Takeda S, et al. A mutation in the ceruloplasmin gene is associated with systemic hemosiderosis in humans. Nat Genet 1995;9:267-72.

113. Kono S, Suzuki H, Takahashi K, et al. Hepatic iron overload associated with a decreased serum ceruloplasmin level in a novel clinical type of aceruloplasminemia. Gastroenterology 2006;131:240-5.

114. Knisely AS, Gelbart T, Beutler E. Molecular characterization of a third case of human atransferrinemia. Blood 2004;104:2607.

115. Mims MP, Guan Y, Pospisilova D, et al. Identification of a human mutation of DMT1 in a patient with microcytic anemia and iron overload. Blood 2005;105:1337-42.

116. Beaumont C, Delaunay J, Hetet G, Grandchamp B, de Montalembert M, Tchernia G. Two new human DMT1 gene mutations in a patient with microcytic anemia, low ferritinemia, and liver iron overload. Blood 2006;107:4168-70.

117. Iolascon A, d'Apolito M, Servedio V, Cimmino F, Piga A, Camaschella C. Microcytic anemia and hepatic iron overload in a child with compound heterozygous mutations in DMT1 (SCL11A2). Blood 2006;107:349-54.

118. Bardou-Jacquet E, Island ML, Jouanolle AM, et al. A novel N491S mutation in the human SLC11A2 gene impairs protein trafficking and in association with the $\mathrm{G} 212 \mathrm{~V}$ mutation leads to microcytic anemia and liver iron overload. Blood Cells Mol Dis 2011;47:243-8.

119. Cox TC, Bottomley SS, Wiley JS, Bawden MJ, Matthews CS, May BK. X-linked pyridoxine-responsive sideroblastic anemia due to a Thr388-to-Ser substitution in erythroid 5-aminolevulinate synthase. N Engl J Med 1994;330:675-9.

120. Allikmets R, Raskind WH, Hutchinson A, Schueck ND, Dean M, Koeller DM. Mutation of a putative mitochondrial iron transporter gene $(A B C 7)$ in X-linked sideroblastic anemia and ataxia (XLSA/A). Hum Mol Genet 1999;8:743-9.

121. Camaschella C, Campanella A, De Falco L, et al. The human counterpart of zebrafish shiraz shows sideroblastic-like microcytic anemia and iron overload. Blood 2007;110:1353-8.

122. Moirand R, Kerdavid F, Loreal O, et al. Regulation of ferritin expression by alcohol in a human hepatoblastoma cell line and in rat hepatocyte cultures. J Hepatol 1995;23:431-9.

123. Eckel RH, Alberti KG, Grundy SM, Zimmet PZ. The metabolic syndrome. Lancet 2010;375:181-3.

124. Mendler $\mathrm{MH}$, Turlin B, Moirand $\mathrm{R}$, et al. Insulin resistance-associated hepatic iron overload. Gastroenterology 1999;117:1155-63.

125. Ruivard M, Laine F, Ganz T, et al. Iron absorption in dysmetabolic iron overload syndrome is decreased and correlates with increased plasma hepcidin. J Hepatol 2009;50:1219-25.

126. Ferrante M, Geubel AP, Fevery J, Marogy G, Horsmans Y, Nevens F. Hereditary hyperferritinaemiacataract syndrome: a challenging diagnosis for the hepatogastroenterologist. Eur J Gastroenterol Hepatol 2005;17:1247-53.

127. Kannengiesser $C$, Jouanolle AM, Hetet $G$, et al. A new missense mutation in the L ferritin coding sequence associated with elevated levels of glycosylated ferritin in serum and absence of iron overload. Haematologica 2009;94:335-9.

128. Girelli D, Bozzini C, Zecchina G, et al. Clinical, biochemical and molecular findings in a series of families with hereditary hyperferritinaemia-cataract syndrome. Br J Haematol 2001;115:334-40.

129. Gandon Y, Olivie D, Guyader D, et al. Non-invasive assessment of hepatic iron stores by MRI. Lancet 2004;363:357-62.

130. St Pierre TG, Clark PR, Chua-anusorn W, et al. Noninvasive measurement and imaging of liver iron concentrations using proton magnetic resonance. Blood 2005;105:855-61.

131. Pietrangelo A, Corradini E, Ferrara F, et al. Magnetic resonance imaging to identify classic and nonclassic forms of ferroportin disease. Blood Cells Mol Dis 2006;37:192-6. 
132. Wood JC, Enriquez C, Ghugre N, et al. MRI R2 and R2* mapping accurately estimates hepatic iron concentration in transfusion-dependent thalassemia and sickle cell disease patients. Blood 2005;106:1460-5.

133. Deugnier Y, Turlin B. Pathology of hepatic iron overload. World J Gastroenterol 2007;13:4755-60.

134. Deugnier Y, Turlin B. Pathology of hepatic iron overload. Semin Liver Dis 2011;31:260-71.

135. Stauber RE, Lackner C. Noninvasive diagnosis of hepatic fibrosis in chronic hepatitis C. World J Gastroenterol 2007;13:4287-94.

136. Crawford DH, Murphy TL, Ramm LE, et al. Serum hyaluronic acid with serum ferritin accurately predicts cirrhosis and reduces the need for liver biopsy in C282Y hemochromatosis. Hepatology 2009;49:41825.

137. Barton JC, Lee PL, West C, Bottomley SS. Iron overload and prolonged ingestion of iron supplements: clinical features and mutation analysis of hemochromatosis-associated genes in four cases. Am J Hematol 2006;81:760-7.

138. Deugnier Y, Loreal O, Carre F, et al. Increased body iron stores in elite road cyclists. Med Sci Sports Exerc 2002;34:876-80.

139. Tanno T, Bhanu NV, Oneal PA, et al. High levels of GDF15 in thalassemia suppress expression of the iron regulatory protein hepcidin. Nat Med 2007;13:1096-101.

140. Musallam KM, Rivella S, Vichinsky E, Rachmilewitz EA. Non-transfusion-dependent thalassemias. Haematologica 2013;98:833-44.

141. Dale JC, Burritt MF, Zinsmeister AR. Diurnal variation of serum iron, iron-binding capacity, transferrin saturation, and ferritin levels. Am J Clin Pathol 2002;117:802-8.

142. Adams PC, Reboussin DM, Press RD, et al. Biological variability of transferrin saturation and unsaturated iron-binding capacity. Am J Med 2007;120:999 e1-7.

143. EASL. EASL clinical practice guidelines for HFE hemochromatosis. J Hepatol 2010;53:3-22.

144. Phatak $P$, Brissot $P$, Wurster $M$, et al. A phase $1 / 2$, dose-escalation trial of deferasirox for the treatment of iron overload in HFE-related hereditary hemochromatosis. Hepatology 2010;52:1671-779. 


\section{LEGENDS TO FIGURE}

Figure 1: Iron metabolism regulation. HCP : Heme carrier protein. DMT1 : Divalent Metal Transporter 1. HJV :

Hemojuvelin. TFR1 : Transferrin Receptor 1. TFR2 : Transferrin Receptor 2. BMP Receptor : Bone Morphegenic Protein receptor.

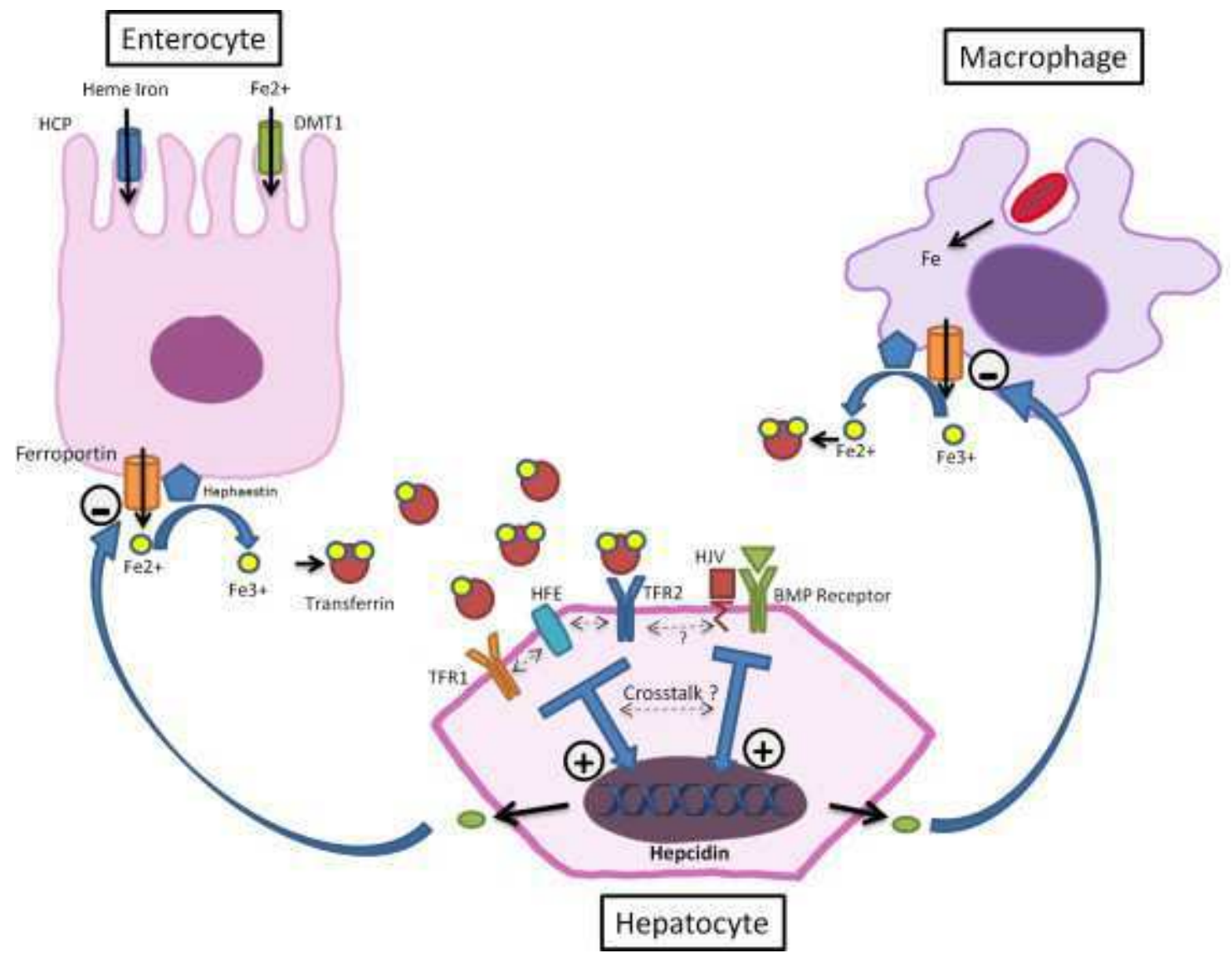


Figure 2: Decision tree for diagnosis of genetic iron overload. HC : Hemochromatosis

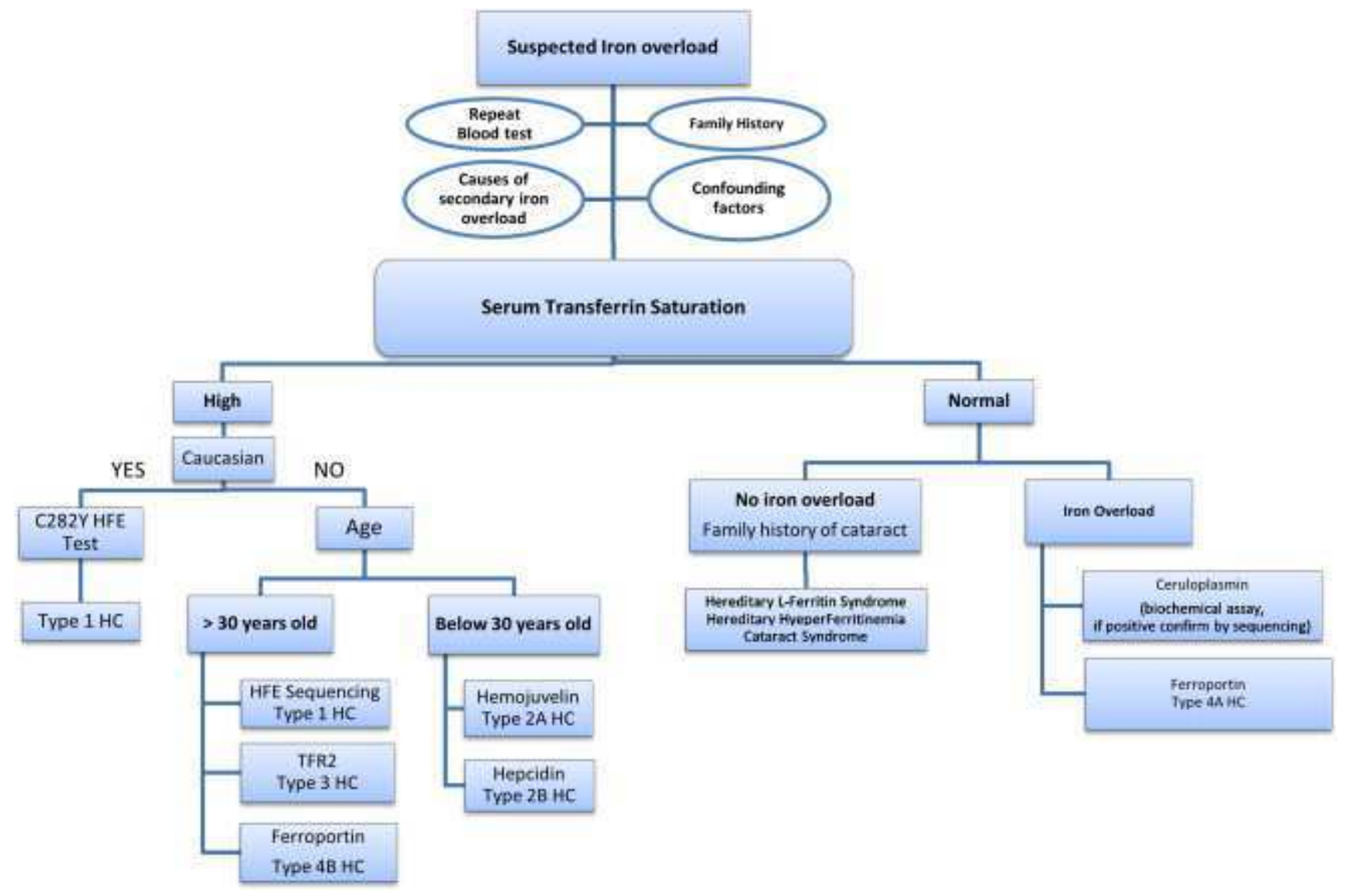

